\title{
IMAGE DAERAH TUJUAN WISATA: SUATU TINJAUAN DARI PERSPEKTIF WISATAWAN NUSANTARA
}

\author{
Martaleni \\ martaleni@yahoo.com
}

Fakultas Ekonomi Universitas Gajayana Malang

\begin{abstract}
Companies increasingly turn to the marketing based on the consumers' image and emotions in order to win mind share and heart share. The management of a tourist destination image is an important factor in achieving success in business tourism. This study aimed to examine the effect of service quality value towards the image, either directly or indirectly through tourist satisfaction as a moderating variable. Data obtained from the domestic tourists who visited tourist destination in Great Malang were analyzed by the method of Partial Least Square (PLS). The findings of this study explains that there are direct and indirect positive influence between the service quality value and the measurement of tourist object attraction, supporting means, empathy and feeling towards tourists' image. Likewise there is a positive influence between satisfaction and tourist image.This study can help marketers (government agencies, private sectors in Great Malang), to better understand the contribution of the image of an increasing number of tourists. Thus marketers will be more careful in designing the right marketing strategy to make tourists more loyal.
\end{abstract}

Keywords: tourist destination, image, service quality, tourist satisfaction.

\section{PENDAHULUAN}

Globalisasi yang terjadi saat ini telah merubah persepsi manusia dalam memandang kegiatan yang dilakukan dalam pariwisata. Kegiatan berwisata telah merupakan kebutuhan yang dipandang sebagai kebutuhan yang sepantasnya terpenuhi dalam suatu keluarga. Di setiap negara berupaya agar bisnis kepariwisataan dapat berkembang dan menjadi sumber andalan untuk meningkatkan devisa. Pariwisata merupakan salah satu industri jasa terbesar di dunia dan merupakan salah satu sektor ekonomi yang sangat strategis yang menimbulkan dampak berganda (multiflier effect), baik secara langsung maupun tidak langsung, sehingga memberikan keuntungan dalam meningkatkan devisa sebuah negara. Dengan demikian daerah-daerah mempunyai peluang yang cukup untuk memperkenalkan potensi pariwisata yang dimilikinya sehingga dapat menarik kunjungan 
wisata baik lokal maupun manca negara (Suradnya, 2008); Lim and McAleer, 2001; Liping et al., 2001; Henderson, 2002; Hanggidae, 2006; Hui et al., 2007; Martaleni, 2010).

Organisasi Perburuhan Internasional (2009), menjelaskan bahwa pada tahun 1950 industri perjalanan (travel) mencatat 25 juta kedatangan internasional. Pada tahun 1980 angka ini telah meningkat menjadi 277 juta dan menjadi 438 juta pada tahun 1990 (tujuh belas kali lipat jika dibandingkan dengan tahun 1950). Pada awal abad ini terdapat 684 juta kedatangan internasional yang tercatat dan meningkat hingga 907 juta pada tahun 2007 dan 922 juta pada tahun 2008. Namun, untuk tahun 2009, UNWTO/Barometer Pariwisata Dunia memperkirakan angka kedatangan internasional secara kasar sejumlah 870 juta (delapan bulan pertama pada tahun 2009 tercatat 600 juta kedatangan internasional). Diproyeksikan pula bahwa pada tahun 2020 kedatangan wisatawan internasional akan tumbuh hingga 1,6 milyar. Pada tahun 2008, pendapatan pariwisata internasional meningkat sebesar 1,7\% secara riil menjadi AS\$ 944.

Pertumbuhan pasar pariwisata secara global tersebut, telah mendorong banyak negara di dunia menggunakan kesempatan untuk melakukan persaingan secara natural dalam industri pariwisata, dengan menawarkan program-program yang diharapkan dapat menarik para wisatawan untuk mengunjungi obyek-obyek wisata yang disediakan. Sebagai contoh, Malaysia menawarkan program yang diberi nama "Truly Asia". Indonesia menawarkan program "Visit Indonesia Year". Hasil dari program-program tersebut, pada tahun 2008, Malaysia dengan program "Truly Asia” nya mampu menjaring 10,6 juta wisatawan mancanegara dengan pertumbuhan 24,4\% pertahun, sedangkan Indonesia dengan program "Visit Indonesia Year" nya mampu mendatangkan sebanyak 4,4 juta wisatawan mancanegara dengan pertumbuhan 1,6 persen per tahun?, jauh tertinggal dari Vietnam yang mencapai angka pertumbuhan $15 \%$ pertahun (WTO, 2007).

Thailand mampu menarik kunjungan 10,1 juta dengan pertumbuhan rata-rata 8,3\% per tahun, negeri mini Singapura yang tak lebih luas dari DKI Jakarta mampu menjaring 6,1 juta dengan pertumbuhan 4,9\% per tahun (Tahun kunjungan Wisata 2008), tetapi bagaimanapun juga, untuk meraih ekonomi potensial pada industri pariwisata global bukanlah hal yang mudah dilakukan oleh negara-negara di dunia ini, meskipun yang dilakukan merupakan persaingan yang natural. Pengembangan dan peningkatan kepariwisataan di Indonesia mendapat dukungan yang sangat kuat dari pemerintah. Hal ini terlihat dengan dikeluarkannya Undang-Undang Republik Indonesia Nomor 10 Tahun 2009 tentang Kepariwisataan. Semangat Undang-undang ini, menuntut Pemerintah daerah untuk selalu berupaya semaksimal mungkin dalam peningkatan pendapatan asli daerah. Berbagai potensi daerah seharusnya dikelola dan diupayakan untuk bisa mendukung dan mewujudkan cita-cita dari Undang-undang tersebut. Tentunya potensi pariwisata juga termasuk yang harus mendapat perhatian. Hal ini sejalan dengan Martaleni (2010) yang menjelaskan bahwa peningkatan pendapatan asli daerah melalui 
pariwisata bisa dilakukan dengan memanfaatkan potensi-potensi yang ada, diantaranya adalah melalui penciptaan kampung-kampung wisata.

Malang Raya, yang terdiri atas Kota Malang, Kabupaten Malang, dan Kota Batu merupakan bagian integral dari negara Indonesia, sehingga Pemerintah Daerah di masingmasing daerah tersebut juga mempunyai kewajiban untuk meningkatkan peran pariwisatanya dalam rangka mendukung roda pembangunan di daerah Malang Raya khususnya, dan di Indonesia pada umumnya. Secara geomorfologis Malang Raya mempunyai potensi yang memungkinkan pertumbuhan dan pengembangan wilayahnya berbasis pada pariwisata, mengingat daerahnya terdiri dari wilayah pegunungan dan dataran, serta perairan pantai yang membentuk bentangan-bentangan alam yang indah dengan patahan-patahan yang menimbulkan air terjun, hamparan pantai yang luas dan berpasir putih.

Berdasarkan potensi obyek dan daya tarik wisata tersebut, nampak bahwa sumber daya alam Malang Raya sangat menunjang untuk pengembangan pariwisata dengan didukung oleh bidang-bidang unggulan seperti pertanian, peternakan, perikanan. Namun demikian usaha untuk meningkatkan pertumbuhan ekonomi melalui pariwisata di Malang Raya, khususnya di Kabupaten Malang tampaknya belum berhasil, ini terlihat dari arus kunjungan wisata baik domestik (wisatawan nusantara) maupun mancanegara (wisatawan mancanegara) di Kabupaten Malang. Menurut Purnadi (2009), terekam data bahwa ratarata jumlah kunjungan wisata di Kabupaten Malang mengalami penurunan cukup signifikan yakni $14 \%$ untuk wisatawan nusantara (wisnus) dan $48 \%$ untuk wisatawan mancanegara (wisman) per tahun.

Terjadinya penurunan jumlah pengunjung tersebut, tidak terlepas dari upaya pemerintah terkait di daerah Malang Raya dalam eksploitasi potensi pariwisata. Hal ini sebagaimana tercantum dalam RENJA-SKPD Kabupaten Malang 2006, yang menjelaskan bahwa eksploitasi secara maksimal dari berbagai potensi pariwisata yang ada di Kabupaten Malang masih belum maksimal. Di samping itu ada beberapa masalah pokok terkait dengan pengembangan pariwisata, antara lain belum maksimalnya pengadaan sarana dan prasarana, belun terciptanya image yang jelas guna membentuk suatu positioning daerah tujuan wisata Malang Raya.

Pertumbuhan pasar pariwisata secara global saat ini mendorong banyak negara di dunia menggunakan kesempatan untuk melakukan strategi pemasaran, misalnya strategi promosi, strategi positioning dan sebagainya. Agar kegiatan promosi dapat berhasil dalam target pasar, daerah tujuan wisata harus menawarkan sesuatu yang berbeda (unik) dibandingkan dengan pesaing atau mendapatkan ruang yang positif dalam pikiran konsumen. Sebagaimana yang dinyatakan oleh Echtner dan Ritchie (2003), Cravens dan Piercy (2003), White (2004), Ibrahim dan Gill (2005), bahwa faktor kunci dalam proses positioning adalah menciptakan dan mengelola sebuah image penting dari suatu daerah 
tujuan wisata. Peneliti pemasaran memberikan berbagai pandangan tentang image dengan penekanan yang beragam (Martaleni, 2010). Kim dan Agrusa (2004) mengungkapkan bahwa negara Australia merupakan tempat bulan madu yang ideal bagi wisatawan dari Korea. Tahun 2005, Kim et al. (2005) melanjutkan penelitianya dengan melakukan kajian serupa di Korea dan menyatakan bahwa Hawaii merupakan tujuan wisata golf yang ideal. Kandampully dan Hu (2007) menyatakan bahwa persaingan pangsa pasar yang semakin kompetitif menjadikan perusahaan kesulitan membedakan perusahaan mereka dengan para pesaingnya. Lebih lanjut ia menyatakan bahwa salah satu cara yang paling efektif untuk meningkatkan image di mata konsumen adalah dengan memberikan pelayanan yang terbaik.

Berbicara tentang kualitas layanan dan image tidak terlepas dari pengukuran kepuasan. Kepuasan konsumen merupakan indikator dari baik atau tidaknya kualitas layanan yang diterima oleh konsumen dan dapat mempengaruhi image dan loyalitas konsumen (Kandampully dan Suhartanto, 2000; Barnes, 2003; Hankinson, 2005; Kandampully dan Hu 2007). Menurut Hankinson (2005) kekuatan hubungan antara image daerah tujuan wisata dan kualitas yang diterima sangat dipengaruhi oleh persepsi terhadap atribut fungsional. Kandampully dan Suhartanto (2000), dan Chen dan Chen (2010) melakukan penelitian tentang peran kepuasan konsumen dan image terhadap loyalitas konsumen, kualitas layanan terhadap image, menyimpulkan bahwa semua variabel tersebut berhubungan positif. Dari uraian di atas dapat dilihat perkembangan kajian tentang kualitas layanan, kepuasan dan image pada obyek kajian yang berbeda dari waktu ke waktu dan dalam beberapa hal selalu ada penyempurnaan. Hal ini mengandung arti bahwa dengan mengkaji penelitian-penelitian terdahulu, para peneliti berikutnya selalu mencari celah guna penyempurnaan dan pengembangan hasil penelitian dibidangnya.

Permasalahan dalan penelitian ini dapat dirumuskan sebagai berikut: Apakah nilai kualitas layanan dan kepuasan wisatawan secara langsung dan tidak langsung berpengaruh positif terhadap image wisatawan.

Berdasarkan permasalahan penelitian, maka tujuan penelitian ini adalah (1) Menguji pengaruh nilai kualitas layanan terhadap kepuasan wisatawan, (2) Menguji pengaruh nilai kualitas layanan terhadap image melalui kepuasan wisatawan dan (3) Menguji pengaruh nilai kualitas layanan terhadap image wisatawan.

\section{TINJAUAN TEORETIS}

\section{Image}

Menciptakan image yang kuat sepenuhnya merupakan bagian dari proses pemasaran. Kotler dan Keller (2006) menyatakan image adalah cara masyarakat mempersepsikan (memikirkan) perusahaan atau produknya. Image dipengaruhi oleh banyak faktor yang di 
luar kendali perusahaan, sehingga "sikap dan tindakan" seseorang terhadap suatu obyek sangat dikondisikan oleh image objek tersebut. Suatu perusahaan akan terlihat melalui image-nya baik yang positif atau negatif. Image yang positif akan memberikan arti yang baik terhadap produk perusahaan tersebut dan seterusnya dapat meningkatkan jumlah penjualan. Sebaliknya penjualan suatu produk akan mengalami penurunan jika image produk dipandang negatif oleh masyarakat. Demikian juga Echtner dan Ritchie (2003) menyatakan bahwa menciptakan dan mengelola image tujuan wisata yang efektif adalah penting untuk strategi positioning dan pemasaran.

Menurut Peters (dalam Jasfar, 2005), suatu perusahaan dikatakan mempunyai Image yang baik bila: (1) Mempunyai kualitas manajemen yang baik, (2) Dapat diukur dari laba yang diperoleh, (3) Perhatian yang tinggi terhadap lingkungan, (4) Mempunyai kesan baik dari sudut pandang karyawan, (5) Selalu berorientasi pada konsumen, (6) Selalu melakukan pembaruan, (7) Memiliki kontribusi penting dalam perekonomian nasional, (8) Mempunyai harapan untuk berkembang lebih lanjut, (9) Mempunyai kualitas barang dan jasa yang tinggi, (10) Aktif dalam memberikan informasi mengenai aktivitas-aktivitas perusahaan pada masyarakat.

Demikaian halnya, Pitana (2009) menyatakan bahwa image merupakan ide atau kepercayaan yang dimiliki wisatawan tentang produk atau pelayanan yang mereka beli atau mereka akan beli. Image destinasi tidak selalu berdasarkan pengalaman atau fakta, tetapi dapat dibentuk sedemikian rupa sehingga menjadi faktor motivasi atau pendorong yang kuat untuk melakukan perjalanan wisata ke destinasi tersebut. Ini memberi arti bahwa kepercayaan, ide, serta impresi seseorang sangat besar pengaruhnya terhadap sikap dan perilaku serta respon yang mungkin akan dilakukannya.

\section{Kualitas Pelayanan}

Penilaian konsumen terhadap kualitas pelayanan berbeda dengan penilaian terhadap produk berwujud. Penilaian kualitas jasa terjadi selama proses penyampaian jasa tersebut. Setiap kontak yang terjadi antara penyedia jasa dengan konsumen merupakan gambaran mengenai suatu "moment of truth", yaitu suatu peluang untuk memuaskan atau tidak memuaskan konsumen. Konsumen selalu berusaha menilai kualitas jasa berdasarkan apa yang dirasakannya, berupa atribut-atribut yang mewakili kualitas jasa, proses jasa, dan kualitas pelayanan.

Kualitas harus dimulai dari kebutuhan konsumen dan berakhir pada persepsi konsumen (Kotler dan Keller, 2006). Hal ini berarti bahwa persepsi tentang kualitas yang baik bukanlah berdasarkan sudut pandang atau persepsi produsen. Konsumenlah yang mengkonsumsi dan menikmati jasa perusahaan, sehingga mereka yang seharusnya menentukan kualitas jasa. Persepsi konsumen terhadap kualitas jasa (consumer perceived service quality) merupakan penilaian menyeluruh atas keunggulan suatu jasa dari sudut pandang konsumen. Namun, perlu diperhatikan bahwa dengan sifat jasa yang tidak nyata 
(intangible) menyebabkan sangat sulit bagi konsumen untuk menilai jasa sebelum dia mengalaminya. Bahkan setelah dia mengkonsumsi jasa tertentu pun, sulit bagi konsumen untuk memberikan penilaian. Gronroos (1990) sebagaimana dikutip oleh Jasfar (2005) dengan menggunakan lima dimensi dari Parasuraman, et al. (1985), menggambarkan bagaimana mekanisme dan ukuran mengenai kualitas jasa oleh konsumen dalam Gambar 1 berikut:

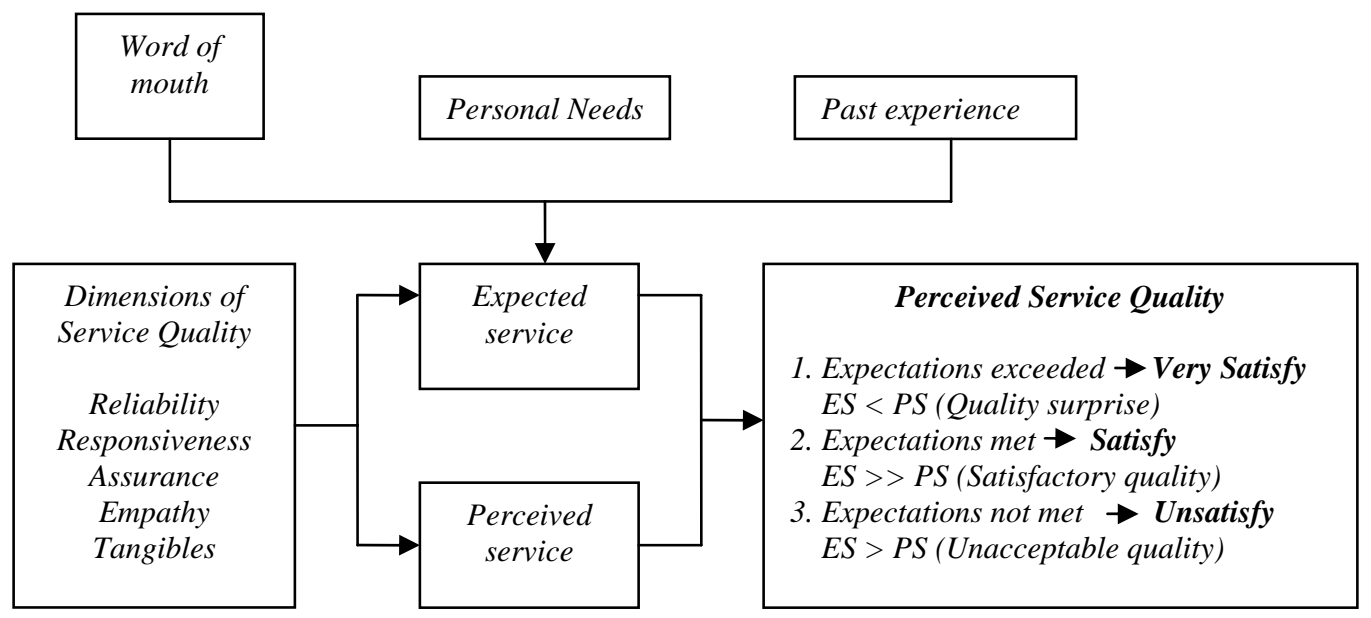

Sumber: Jasfar (2005)

\section{Gambar 1 \\ Mekanisme dan Ukuran Kualitas Jasa Bagi Konsumen}

Dalam konteks penilaian kualitas produk maupun jasa telah diperoleh kesepakatan, bahwa harapan konsumen memiliki peranan yang besar sebagai standar perbandingan dalam evaluasi kualitas maupun kepuasan. Untuk membuktikan apakah kualitas produk baik atau tidak, dapat diukur dari tingkat kepuasan konsumen. Kepuasan konsumen terhadap suatu jasa adalah perbandingan antara persepsi konsumen terhadap jasa yang diterima dengan harapannya sebelum menggunakan jasa tersebut. Apabila harapannya terlampaui, berarti jasa tersebut telah memberikan suatu kualitas yang luar biasa dan juga akan menimbulkan kepuasan yang sangat tinggi (very satisfy). Sebaliknya, apabila harapannya itu tidak tercapai, maka diartikan kualitas jasa tersebut tidak memenuhi apa yang diinginkannya atau perusahaan tersebut gagal melayani konsumennya. Apabila harapannya sama dengan apa yang dia peroleh, berarti konsumen itu puas/satisfy (Jasfar, 2005; Kotler dan Keller, 2006).

\section{Dimensi Kualitas Jasa}

Parasuraman et al.(1985) melakukan penelitian khusus terhadap beberapa jenis industri jasa. Peneliti berhasil mengidentifikasi sepuluh faktor yang dinilai konsumen dan merupakan faktor utama yang menentukan kualitas jasa, yaitu access, communication, 
competence, courtesy, credibility, reliability, responsivness, security, understanding, dan tangibles.

Selanjutnya, Parasuraman et al. (1988) melakukan kembali penelitian pada beberapa industri jasa dalam rangka pengembangan dan redefinisi servqual. Ditemukan hasil bahwa terdapat hubungan yang sangat kuat antara communication, competence, courtesry, creadibility, dan security yang kemudian dikelompokkan menjadi satu dimensi, yaitu assurance. Demikian pula halnya ditemukan hubungan yang sangat kuat di antara access dan understanding, yang kemudian digabung menjadi satu dimensi, yaitu empathy. Akhirnya, dari sepuluh faktor di atas dikelompokkan menjadi lima dimensi kualitas jasa, yaitu reliability (kehandalan), responsiveness (daya tahan), assurance (jaminan), empathy (empati), dan tangible (produk-produk fisik).

a. Reliability (kehandalan) adalah kemampuan untuk memberikan pelayanan yang dijanjikan dengan tepat (accurately) dan kemampuan untuk dipercaya (dependeably), terutama memberikan jasa secara tepat waktu (on time), dengan cara yang sama sesuai dengan jadwal yang telah dijanjikan dan tanpa melakukan kesalahan setiap kali.

b. Responsiveness (daya tanggap) adalah kemauan atau keinginan para karyawan untuk membantu dan memberikan jasa yang dibutuhkan konsumen. Membiarkan konsumen menunggu, terutama tanpa alasan yang jelas akan menimbulkan kesan negatif yang tidak seharusnya terjadi. Apabila terjadi kesalahan lalu ditanggapi dengan cepat, maka tanggapan tersebut bisa menjadi sesuatu yang berkesan dan menjadi pengalaman yang menyenangkan. Contoh ketika terjadi keterlambatan keberangkatan pesawat, lalu penumpang diberikan makan dan minum. Hal ini akan menjadi pengalaman yang menyenangkan bagi penumpang.

c. Assurance (jaminan) meliputi pengetahuan, kemampuan, keramahan, sopan, dan sifat dapat dipercaya dari kontak personal untuk menghilangkan sifat keragu-raguan konsumen dan merasa terbebas dari bahaya dan resiko.

d. Empathy (empati) meliputi sikap kontak personel maupun perusahaan untuk memahami kebutuhan maupun kesulitan konsumen, komunikasi yang baik, perhatian pribadi, kemudahan dalam melakukan komunikasi atau hubungan.

e. Tangibles (produk-produk fisik) adalah tersedianya fasilitas fisik, perlengkapan dan sarana komunikasi, dan lain-lain yang dapat dan harus ada dalam proses jasa.

\section{Kepuasan Konsumen}

Barnes (2003) mendefinisikan kepuasan konsumen sebagai tanggapan atas terpenuhinya kebutuhan. Hal ini berarti bahwa suatu bentuk keistimewaan dari suatu barang atau jasa, memberikan tingkat kenyamanan yang terkait dengan pemenuhan suatu kebutuhan, termasuk pemenuhan kebutuhan di bawah harapan atau pemenuhan kebutuhan melebihi harapan konsumen. Dari definisi di atas dapat dijelaskan bahwa pada dasarnya kepuasaan konsumen mencakup perasaan senang atau tidak senang seseorang setelah membanding perbedaan antara harapan (outcome) dan prestasi (performance) atau hasil yang diterima. 
Menurut Fournier dan Mick (dalam Barnes, 2003) ada lima kesimpulan penting tentang kepuasan konsumen: (a) Kepuasan konsumen adalah suatu proses efektif dan dinamis, (b) Kepuasan tersebut seringkali memiliki dimensi sosial yang kuat, (c) Makna dan emosi merupakan komponen integral dari kepuasan, (d) Proses kepuasan bergantung pada konteks dan saling berhubungan, meliputi berbagai paradigma, model dan mode, (e) Kepuasan produk selalu berkaitan dengan kepuasan hidup dan kualitas hidup itu sendiri.

Implikasi dari kesimpulan-kesimpulan di atas penting bagi para manajer yang berharap mencapai tingkat kepuasan konsumen yang lebih tinggi. Dengan demikian akan ada kemungkinan mendatangkan keuntungan dari kepuasan konsumen pada level rata-rata yang lebih tinggi. Pencapain kepuasan konsumen merupakan suatu proses yang dinamis dan tidak pernah berhenti karena pekerjaan yang tidak pernah selesai, aturan-aturan yang selalu berubah, dan lingkungan yang selalu berubah-ubah dengan munculnya pesaingpesaing baru. Sesuatu yang dulu dianggap sebagai pengalaman yang "Wah” akan berubah menjadi sesuatu yang biasa.

\section{Bagaimana Menentukan Kepuasan Konsumen}

Kepuasan konsumen merupakan pengaruh dari spesifikasi yang dimiliki oleh suatu produk atau jasa dan persepsi konsumen terhadap kualitas. Zeithaml dan Bitner (2004) menyatakan bahwa kepuasan konsumen juga dipengaruhi oleh:

a. Emosi Konsumen (Consumer Emotions). Emosi konsumen dapat berdampak pada persepsi dan kepuasan konsumen dari suatu produk atau jasa. Ketika konsumen sedang merasakan kesenangan (happy mood), konsumen cenderung memberikan penilaian positif terhadap jasa yang diterima dan sebaliknya bila konsumen sedang merasakan kesusahan (bad mood) cenderung menilai negatif terhadap jasa yang diterima.

b. Atribut dari Keberhasilan dan kegagalan jasa (Attributions For Service Success or failure). Atribut sebuah produk atau jasa yang dirasakan konsumen dapat mempengaruhi persepsi terhadap kepuasan. Ketika konsumen merasa puas dengan outcome suatu produk, konsumen cenderung untuk mengetahui penyebabnya dan memperkirakan penyebab yang membuat mereka puas.

c. Persepsi terhadap equity dan kejujuran (Perceptions of Equity or Fairness). Kepuasan konsumen juga dipengaruhi oleh persepsi terhadap keadilan dan kejujuran dari produk atau jasa yang ditawarkan. Konsumen dapat melakukan reaksi keras atau komplain pada suatu perusahan yang menawarkan suatu produk yang tidak dilandasi dengan keadilan dan kejujuran.

Menurut Kotler dan keller (2006), ada sejumlah metode yang dapat digunakan untuk mengukur kepuasan pelanggan, seperti:

a. Survei secara periodik (periodic surveys)

Dengan melakukan survey langsung pada pelanggan, dengan demikian akan dapat dipahami tanggapan atau rekomendasi dari pelanggan terhadap produk yang 
dibelinya dari perusahaan. Perusahan dapat memperoleh informasi tentang merek, kualitas, ukuran dan pelayanan yang di inginkan dari pelanggan.

b. Pembelian siluman (mystery shoppers)

Mengirim seseorang atau manajer langsung yang berperan sebagai konsumen potensial dan melaporkan tentang pelayanan yang diberikan pada pelanggan atau pada sesama karyawan.

c. Menilai pelanggan yang hilang (customer loss rate)

Perusahaan dapat memonitor pelanggan yang hilang dan mengapa mereka tidak lagi melakukan pembelian. Hilangnya pelanggan dapat disebabkan karena pelayanan yang kurang baik, harga yang tidak bersaing, pindah tempat kerja atau karena hal-hal lain.

Berdasarkan pada tinjauan teoretis, maka dapat disusun rerangka konseptual, sebagaimana terlihat pada Gambar 2 berikut:

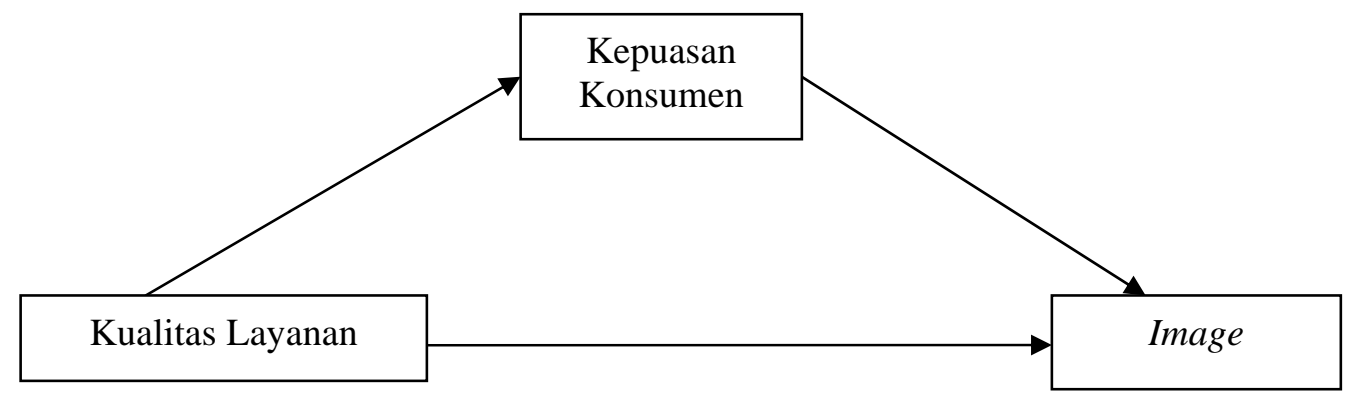

Gambar 2

Rerangka Konseptual Penelitian

\section{Hipotesis Penelitian}

H1: Semakin tinggi nilai kualitas layanan, akan semakin meningkat kepuasan wisatawan H2: Semakin tinggi nilai kualitas layanan, secara tidak langsung akan meningkatkan image wisatawan melalui kepuasan.

H3: Semakin tinggi nilai kualitas layanan, akan semakin meningkat image wisatawan.

\section{METODE PENELITIAN}

Penelitian ini adalah penelitian positivist, karena bertujuan menguji pengaruh independen variabel terhadap dependen variabel, yang selanjutnya dapat digunakan sebagai dasar pembuatan keputusan (Creswell, 2009). Objek kajian dari penelitian ini adalah wisatawan nusantara (wisnus) yang mengunjungi daerah tujuan wisata Malang Raya. Pengambilan sampel sebanyak 232 responden dilakukan secara purposive sampling, yaitu wisatawan yang datang dari luar daerah Malang Raya dan berusia minimal 15 tahun. Hair (2006), Solimun (2008) menjelaskan bahwa purposive sampling adalah teknik pengambilan 
sampel berdasarkan pertimbangan-pertimbangan tertentu. Penelitian ini menggunakan kuesioner sebagai instrumen dan diukur dengan skala Likert lima kategori. Variabel yang akan dianalisis diklasifikasikan menjadi dua kelompok, yakni variabel eksogen dan variabel endogen. Dalam penelitian ini, ada dua variabel eksogen yaitu: kualitas layanan dan kepuasan konsumen, sedangkan variabel endogen merupakan variabel yang nilainya tergantung dari variasi perubahan nilai variabel lainnya. Variabel endogen dalam penelitian ini terdiri dari: variabel image.

Untuk menunjukkan sejauh mana suatu alat pengukur (instrument) mengukur apa yang ingin diukur dan untuk menunjukkan apakah instrumen yang digunakan cukup akurat, akan dilakukan uji validitas dan reliabilitas. Teknik analisa data yang dipergunakan dalam penelitian adalah teknik analisis statistik deskriptif dan teknik analisis statistik inferensial. Teknik analisis inferensial yang digunakan adalah: Structural Equation Modeling berbasis Component (CBSEM) yang umum dikenal dengan Partial Least Square atau PLS (Solimun, 2008; Hair, 2006). Perhitungan dalam analisis data dengan paket program SmartPLS.

\section{ANALISIS DAN PEMBAHASAN}

\section{Pengujian Validitas dan Reliabilitas}

Dari hasil pengujian outer weight menunjukkan bahwa untuk variabel kualitas layanan semua indikatornya sudah valid dengan $p$-value $\leq 0.50$. Untuk variabel kepuasan konsumen dan image konsumen sudah memenuhi persyaratan validitas konvergen karena seluruh butir pertanyaan memiliki nilai outer loadings $>0.5$ dan $t$-statistics di atas 1.96. Berdasarkan hasil analisis discriminant validity, dapat diinterpretasikan bahwa variabel kepuasan dan image konsumen telah memenuhi discriminant validity, sedangkan uji reliabilitas instrumen diperoleh nilai composite reliability (tabel 1) semuanya lebih besar dari 0.7, sehingga dapat disimpulkan bahwa seluruh indikator dari masing-masing variabel adalah reliabel.

Tabel 1

Hasil Perhitungan Composite Reliability

\begin{tabular}{lc}
\hline \hline & Composite Reliability \\
\hline $\mathrm{X}_{1}$ (Kualitas Layanan) & - \\
$\mathrm{X}_{2}$ (Kepuasan Wisatawan) & 0.894 \\
$\mathrm{Y}$ (Image) & 0.853 \\
\hline Sumber: data primer di olah, 2010
\end{tabular}

Sumber: data primer di olah, 2010 


\section{Pengujian Model Hubungan Antar Variabel (Goodness of Fit)}

Pengujian goodness of fit model memperoleh nilai predictive relevance sebesar 0.9014. Hal ini mengindikasikan bahwa model sudah sangat baik karena variabel-variabel yang terlibat mampu menjelaskan variabel yang mempengaruhi image wisatawan (Y) sebesar $90.14 \%$. Sisanya kurang dari 10\% merupakan faktor lain yang turut mempengaruhi image wisatawan (Y) yang belum dimasukkan dalam kajian penelitian ini.

\section{Hasil Outer Loading}

Dari hasil analisis, diperoleh loading factor yang dapat dijadikan sebagai landasan untuk menentukan indikator/butir pertanyaan yang mana yang paling kuat mempengaruhi variabel. Berikut adalah loading factor yang dihasilkan masing-masing butir pertanyaan untuk variabel kualitas layanan (X1).

Tabel 2

Hasil loading factor variabel Kualitas Layanan $\left(\mathrm{X}_{1}\right)$

\begin{tabular}{|c|c|c|c|}
\hline Indikator & $\begin{array}{c}\text { Outer } \\
\text { Weight }\end{array}$ & Indikator & $\begin{array}{c}\text { Outer } \\
\text { Weight }\end{array}$ \\
\hline $\begin{array}{l}\text { Daya Tarik Obyek Wisata } \\
\left(\mathrm{X}_{1.1}\right)\end{array}$ & 0,251 & $\begin{array}{l}\text { Perasaan } \\
\text { (feelings })\left(\mathrm{X}_{1.4}\right)\end{array}$ & 0,456 \\
\hline Sarana Pendukung $\left(\mathrm{X}_{1.2}\right)$. & 0,211 & $\begin{array}{l}\text { indikator Empati } \\
\left(\mathrm{X}_{1.3}\right)\end{array}$ & 0,369 \\
\hline Indikator Empati $\left(\mathrm{X}_{1.3}\right)$ & 0,369 & $\begin{array}{l}\text { Daya Tarik Obyek } \\
\text { Wisata }\left(\mathrm{X}_{1.1}\right)\end{array}$ & 0,251 \\
\hline Perasaan (feelings) $\left(\mathrm{X}_{1.4}\right)$ & 0,456 & $\begin{array}{l}\text { Sarana Pendukung } \\
\left(\mathrm{X}_{1.2}\right) \text {. }\end{array}$ & 0,211 \\
\hline
\end{tabular}

Sumber: data primer di olah, 2010

Dari tabel 2 dapat dilihat bahwa perasaan (feelings)( $\left.\mathrm{X}_{1.4}\right)$ merupakan indikator yang paling kuat mempengaruhi variabel kualitas layanan $\left(\mathrm{X}_{1}\right)$ diikuti oleh indikator empati $\left(\mathrm{X}_{1.3}\right)$ dan daya tarik obyek wisata $\left(\mathrm{X}_{1.1}\right)$, sedangkan indikator yang paling lemah mempengaruhi variabel kualitas layanan $\left(\mathrm{X}_{1}\right)$ adalah indikator sarana pendukung $\left(\mathrm{X}_{1.2}\right)$.

Tabel 3

Hasil loading factor variabel Kepuasan Wisatawan (X2)

\begin{tabular}{lcccc}
\hline \hline \multicolumn{1}{c}{ Indikator } & $\begin{array}{c}\text { Outer } \\
\text { Loading }\end{array}$ & & \multicolumn{1}{c}{ Indikator } & $\begin{array}{c}\text { Outer } \\
\text { Loading }\end{array}$ \\
\cline { 4 - 5 } $\begin{array}{l}\text { Kepuasan terhadap daya } \\
\text { tarik obyek wisata }\left(\mathrm{X}_{2.1}\right)\end{array}$ & 0,856 & $\square$ & $\begin{array}{l}\text { Kepuasan terhadap daya } \\
\text { tarik obyek wisata }\left(\mathrm{X}_{2.1}\right)\end{array}$ & 0,856 \\
$\begin{array}{l}\text { Kepuasan terhadap } \\
\text { sarana pendukung }\left(\mathrm{X}_{2.2}\right)\end{array}$ & 0,849 & & $\begin{array}{l}\text { Kepuasan terhadap } \\
\text { sarana pendukung }\left(\mathrm{X}_{2.2}\right)\end{array}$ & 0,849 \\
& & &
\end{tabular}

Image Daerah Tujuan Wisata (Martaleni) 
Tabel 3 lanjutan

\begin{tabular}{lclc}
\hline \hline \multicolumn{1}{c}{ Indikator } & $\begin{array}{c}\text { Outer } \\
\text { Loading }\end{array}$ & \multicolumn{1}{c}{ Indikator } & $\begin{array}{c}\text { Outer } \\
\text { Loading }\end{array}$ \\
\hline $\begin{array}{l}\text { Kepuasan terhadap } \\
\text { perhatian petugas dan }\end{array}$ & 0,792 & $\begin{array}{l}\text { Kepuasan terhadap } \\
\text { suasana hati ketika } \\
\text { berada di daerah wisata } \\
\left(\mathrm{X}_{2.4}\right)\end{array}$ & 0,793 \\
$\begin{array}{l}\text { Kenduduk setempat }\left(\mathrm{X}_{2.3}\right) \\
\text { Kepuasan terhadap }\end{array}$ & $\begin{array}{l}\text { Kepuasan terhadap } \\
\text { perhatian petugas dan }\end{array}$ & 0,792 \\
$\begin{array}{l}\text { berada di daerah wisata } \\
\left(\mathrm{X}_{2.4}\right)\end{array}$ & 0,793 & $\begin{array}{l}\text { penduduk setempat } \\
\left(\mathrm{X}_{2.3}\right)\end{array}$ & \\
\hline
\end{tabular}

Sumber: data primer di olah, 2010

Berikut adalah loading factor yang dihasilkan masing-masing butir pertanyaan untuk variabel image konsumen $(\mathrm{Y})$ :

Tabel 4

Hasil loading factor variabel Image (Y3)

\begin{tabular}{|c|c|c|c|}
\hline $\begin{array}{c}\text { Indikator } \\
\text { Daerah Tujuan Wisata } \\
\text { Malang Raya sebagai: }\end{array}$ & $\begin{array}{l}\text { Outer } \\
\text { Loading }\end{array}$ & Indikator & $\begin{array}{c}\text { Outer } \\
\text { Loading }\end{array}$ \\
\hline Wisata rekreasi $\left(\mathrm{Y}_{3.1}\right)$ & 0,698 & Wisata belanja $\left(\mathrm{Y}_{3.3}\right)$ & 0,732 \\
\hline Wisata agro dan bunga $\left(\mathrm{Y}_{3.2}\right)$ & 0,554 & Wisata kuliner $\left(\mathrm{Y}_{3.6}\right)$ & 0,726 \\
\hline Wisata belanja $\left(\mathrm{Y}_{3.3}\right)$ & 0,732 & Wisata rekreasi $\left(\mathrm{Y}_{3.1}\right)$ & 0,698 \\
\hline Wisata budaya $\left(\mathrm{Y}_{3.4}\right)$ & 0,680 & Wisata religi $\left(\mathrm{Y}_{3.7}\right)$ & 0,695 \\
\hline Wisata alam $\left(\mathrm{Y}_{3.5}\right)$ & 0,615 & Wisata budaya $\left(\mathrm{Y}_{3.4}\right)$ & 0,680 \\
\hline Wisata kuliner $\left(\mathrm{Y}_{3.6}\right)$ & 0,726 & Wisata alam $\left(\mathrm{Y}_{3.5}\right)$ & 0,615 \\
\hline Wisata religi $\left(\mathrm{Y}_{3.7}\right)$ & 0,695 & $\begin{array}{l}\text { Wisata agro dan } \\
\text { bunga }\left(\mathrm{Y}_{3.2}\right)\end{array}$ & 0,554 \\
\hline
\end{tabular}

Sumber: data primer di olah, 2010

Dari tabel 4 bisa dilihat bahwa pendapat yang menyatakan daerah tujuan wisata Malang Raya merupakan wisata belanja $\left(\mathrm{Y}_{3.3}\right)$ merupakan indikator yang paling kuat mempengaruhi variabel image (Y3) diikuti oleh indikator daerah tujuan wisata Malang Raya merupakan wisata kuliner $\left(\mathrm{Y}_{3.6}\right)$ dan indikator daerah tujuan wisata Malang Raya merupakan wisata rekreasi $\left(\mathrm{Y}_{3.1}\right)$, sedangkan indikator yang paling lemah mempengaruhi variabel image (Y3) adalah indikator daerah tujuan wisata Malang Raya sebagai wisata agro dan bunga $\left(\mathrm{Y}_{3.2}\right)$. 


\section{Hasil Pengujian Hipotesis Penelitian}

Hasil Analisis Partial Least Square (PLS) dapat dilihat pada tabel 5 berikut.

Tabel 5

Hasil Analisis Pengaruh Masing-masing Variabel

(Inner Weights)

\begin{tabular}{|c|c|c|c|c|c|c|c|c|c|}
\hline & \multirow{2}{*}{$\begin{array}{c}\text { Variabel } \\
\text { Independen }\end{array}$} & \multirow{2}{*}{$\begin{array}{l}\text { Variabel } \\
\text { Dependen }\end{array}$} & \multicolumn{4}{|c|}{$\begin{array}{c}\text { Koefisien Jalur } \\
\text { Direct Effect }\end{array}$} & \multicolumn{3}{|c|}{$\begin{array}{l}\text { Koefisien Jalur } \\
\text { Indirect Effect }\end{array}$} \\
\hline & & & $\begin{array}{c}\text { Std- } \\
\text { ize }\end{array}$ & $\begin{array}{c}t- \\
\text { stat }\end{array}$ & $\begin{array}{c}P \text { - } \\
\text { value }\end{array}$ & Ket. & $\begin{array}{c}\text { Variabel } \\
\text { Moderating }\end{array}$ & $\begin{array}{c}\text { Std- } \\
\text { ize }\end{array}$ & Ket \\
\hline $\mathrm{H}_{1}$ & $\begin{array}{l}\text { Kualitas } \\
\text { Layanan } \\
\text { (X1) }\end{array}$ & $\begin{array}{l}\text { Kepuasan } \\
\text { Wisatawan } \\
\text { (X2) }\end{array}$ & 0,726 & $\begin{array}{r}11,3 \\
9\end{array}$ & 0,000 & Sig & & & \\
\hline $\mathrm{H}_{3}$ & $\begin{array}{l}\text { Kualitas } \\
\text { Layanan } \\
\text { (X1) }\end{array}$ & $\begin{array}{l}\text { Image } \\
\text { Wisatawan } \\
\text { (X3) }\end{array}$ & 0,467 & 5,07 & 0,000 & Sig & $\begin{array}{l}\text { Kepuasan } \\
\text { Wisatawan } \\
\text { (X2) }\end{array}$ & 0,250 & Sig \\
\hline $\mathrm{H}_{4}$ & $\begin{array}{l}\text { Kepuasan } \\
\text { Wisatawan } \\
\text { (X2) }\end{array}$ & $\begin{array}{l}\text { Image } \\
\text { Wisatawan } \\
\text { (X3) }\end{array}$ & 0,345 & 3,83 & 0,000 & Sig & & & \\
\hline
\end{tabular}

Ket: signifikan pada taraf $5 \%$

Berdasarkan hasil analisis pada Tabel 5 dapat dijelaskan bahwa semua hipotesis diterima dengan $p$ value sebesar 0.000. Ini berarti bahwa terdapat pengaruh positif yang signifikan.

\section{Pembahasan}

\section{Persepsi Responden Terhadap Variabel Penelitian}

Pada tabel 2 dapat dilihat bahwa perasaan (feelings) merupakan indikator utama dalam membentuk kualitas layanan. Penelitian ini memperkuat temuan dari penelitian Uysal, et al. (2000) yang mengatakan bahwa feelings merupakan atribut yang sangat penting bagi pengunjung suatu daerah tujuan wisata.

Kuatnya pengaruh indikator perasaan (feelings) yang membentuk dan mempengaruhi kualitas layanan, dapat diartikan bahwa daerah tujuan wisata Malang Raya sebagai daerah wisata yang terdiri dari wilayah pegunungan, dataran serta perairan pantai yang berpasir putih membentuk bentangan-bentangan alam yang indah dengan patahan-patahan yang menimbulkan air terjun, menjadikan daerah wisatanya memiliki alam yang sejuk. Untuk itu dinas pariwisata yang tergabung dalam daerah tujuan wisata Malang Raya, perlu mempertahankan dan meningkatkan kekuatan atribut dari kualitas layanan yang dimiliki. 
Empati merupakan indikator kedua mempengaruhi kualitas layanan, artinya pelayanan di daerah tujuan wisata Malang Raya perlu ditingkatkan dengan pemberian layanan yang lebih ramah, lebih tanggap, tidak diskriminatif dan penduduk sekitar yang bersahabat. Berdasarkan wawancara dengan beberapa wisatawan yang datang ke daerah tujuan wisata Malang Raya, dapat diperoleh informasi tentang perhatian masyarakat sekitar daerah wisata dianggapnya cukup ramah dan bersahabat sebagaimana juga penilaian wisatawan mancanegara terhadap citra pariwisata Indonesia. Indikator daya tarik obyek wisata merupakan urutan ketiga dalam mempengaruhi kualitas layanan. Artinya wisatawan memandang daya tarik obyek wisata memiliki pengaruh yang kecil dalam membentuk kualitas layanan sebuah daerah tujuan wisata.

Sarana pendukung merupakan indikator yang paling lemah dalam membentuk kualitas layanan suatu daerah tujuan wisata. Ini dapat diartikan bahwa wisatawan memandang sarana pendukung berperan sebagai penunjang dalam membentuk kualitas layanan daerah tujuan wisata Malang Raya.

Pada tabel 3 dapat dilihat bahwa kepuasan wisatawan yang dijelaskan dengan indikator kesesuaian dengan harapan akan daya tarik obyek wisata merupakan indikator paling kuat dalam menjelaskan kepuasan wisatawan. Artinya bahwa daya tarik obyek wisata yang ditawarkan telah mampu memenuhi harapan wisatawan dalam mengunjungi daerah tujuan wisata Malang Raya.

Dari kajian ini, dapat dijelaskan bahwa daerah tujuan wisata Malang Raya dapat mempertahankan dan terus menggali potensi daya tarik obyek wisata yang ditawarkan. Untuk mendukung kekuatan daya tarik obyek wisata sebagai indikator yang merefleksikan kepuasan wisatawan, selalu melakukan edukasi pada petugas dan penduduk setempat agar dapat memberikan layanan dan perhatian pada wisatawan, membenahi dan mengembangkan tempat-tempat yang dirasakan sebagai tempat yang dapat membuat terpenuhi kebutuhan wisatawan, sehingga dapat menunjang dan meningkatkan nilai (added value) dari daya tarik obyek wisata yang dinikmati oleh wisatawan.

Kesesuain dengan harapan akan sarana pendukung, merupakan indikator yang menempati posisi kedua dalam mempengaruhi kepuasan konsumen. Artinya sarana pendukung berupa tempat layanan informasi, tempat parkir yang memadai, fasilitas toilet yang nyaman, tempat ibadah yang mudah dijangkau dan tempat penginapan yang nyaman dan strategis yang tersedia di daerah tujuan wisata Malang Raya mampu memenuhi harapan wisatawan.

Indikator kesesuaian dengan harapan perhatian oleh petugas dan penduduk setempat yang bersahabat merupakan indikator yang menempati posisi ketiga dalam mempengaruhi kepuasan konsumen. Hal ini dapat dimaknai bahwa perhatian dari petugas perlu 
mendapatkan perhatian pihak berwenang untuk ditingkatkan melalui pendidikan, pelatihan dan aktifitas-aktifitas lain yang dapat menunjang peningkatan pelayanan petugas pada wisatawan.

Indikator kesesuian dengan harapan suasana hati yang dirasakan ketika berada di daerah tujuan wisata Malang Raya menempati posisi keempat dalam mempengaruhi kepuasan wisatawan. Artinya indikator perasaan (feelings) sebagai pembentuk kualitas layanan belum mampu memberikan kontribuasi yang kuat pada pemenuhan kepuasan wisatawan.

Pada tabel 4 dapat dilihat bahwa image utama daerah tujuan wisata Malang Raya merupakan wisata belanja. Hal ini dapat dijelaskan bahwa wisatawan memiliki kesan Malang Raya sebagai daerah tujuan wisata belanja. Temuan ini sejalan dengan program pemerintah kota Malang yang berencana akan membuka pasar seni sebagai upaya meningkatkan daya tarik wisata dan program memajukan wisata belanja oleh Asosiasi Pengelola Pusat Belanja (APPBI). Demikian juga wawancara yang dilakukan pada wisatawan, diperoleh informasi bahwa setelah menikmati beberapa obyek wisata, wisatawan selalu memiliki agenda terakhir ke tempat-tempat belanja seperti Malang Town Square (Matos), tempat belanja sekitar alun-alun dan ke tempat lain sebagai obyek wisata belanja.

Selain image wisatawan terhadap daerah tujuan wisata sebagai wisata belanja, daerah tujuan wisata Malang Raya juga memiliki image sebagai wisata kuliner. Image sebagai wisata alam dan wisata agro (petik apel dan wisata bunga) memiliki nilai indikator yang rendah dalam penggambaran sebuah image daerah tujuan wisata Malang Raya. Hal ini berarti bahwa wisatawan kurang memiliki kesan pada daerah tujuan wisata Malang Raya sabagai daerah wisata yang memiliki alam yang bagus dan daerah yang banyak menghasilkan apel.

\section{a. Pengaruh Kualitas Layanan Terhadap Kepuasan Wisatawan}

Kualitas layanan berpengaruh signifikan yang positif terhadap kepuasan konsumen. Temuan penelitian ini konsisten dengan teori service (Jasfar, 2005; Kotler dan Keller, 2006) yang menjelaskan bahwa apabila kualitas layanan yang dirasakan melampaui harapan konsumen, berarti jasa tersebut telah memberikan suatu kualitas yang luar biasa dan juga akan menimbulkan kepuasan yang sangat tinggi (very satisfy). Sebaliknya, apabila harapannya itu tidak tercapai, maka diartikan kualitas jasa tersebut tidak memenuhi apa yang diinginkannya atau perusahaan tersebut gagal melayani konsumennya. Apabila harapannya sama dengan apa yang di peroleh, berarti konsumen itu puas (satisfy).

Secara empiris, temuan penelitian ini juga sejalan dengan hasil penelitian Bei dan YuChing (2001), Pawitra dan Tan (2003), Juwaheer (2004), Ibrahim dan Gill (2005), Andaleeb (2006), Kandampully dan Hu (2007) yang menjelaskan bahwa kualitas layanan 
berpengaruh signifikan terhadap kepuasan wisatawan. Obyek kajian dari penelitianpenelitian tersebut tidak seluruhnya pada daerah tujuan wisata, namun meskipun obyek kajian atau negara berbeda temuan dari penelitian tersebut juga berlaku pada penelitian ini. Di sisi lain hasil penelitian ini bertentangan dengan temuan penelitian dari Reisinger (1994), Coreria dan Valle (2007), Hutcinson, et al. (2009) yang mengatakan bahwa kualitas layanan tidak berpengaruh signifikan terhadap kepuasan konsumen.

Reisinger (1994) melakukan analisis tentang kepuasan wisatawan Jepang terhadap layanan toko di Australia. Sementara itu Correia dan Valle (2007) melakukan penelitian tentang "Why people travel to exotic places". Hasil analisisnya menjelaskan bahwa wisatawan Portugis tidak puas terhadap kualitas layanan yang ditawarkan, karena wisatawan yang datang ke tempat wisata tidak hanya bermotivasi untuk berwisata tapi juga untuk memecahkan konflik yang dirasakan. Seseorang yang sedang dalam kondisi kesusahan (bad mood) akan cenderung memiliki persepsi negatif terhadap kualitas layanan yang diterima (Zaithaml dan Bitner, 2004), sehingga kualitas layanan yang diterima tidak memuaskan yang bersangkutan. Selanjutnya bersumber dari adanya perbedaan persepsi tentang atribut yang ditawarkan, penyedia jasa tempat-tempat eksotik memandang istirahat dan relaksasi sebagai perspektif fisik. Sementara itu wisatawan Portugis nampaknya memahami istirahat dan relaksasi dari sudut pandang yang berbeda,"istirahat dan relaksasi tidak berarti tidak melakukan apapun, namun melakukan ha-hal yang berbeda”.

Empati merupakan indikator yang berada pada posisi kedua dalam membentuk kualitas layanan. Hasil tersebut dapat memberikan informasi terutama pada pengelola obyek wisata, bahwa para petugas layanan di daerah tujuan wisata Malang Raya perlu perhatian dan pembinaan. Hal ini dalam rangka mewujudkan keinginan para wisatawan agar para petugas layanan dapat memberikan layanan yang ramah dan dapat memberikan informasi yang dibutuhkan wisatawan. Di samping para petugas, pembinaan terhadap masyarakat setempat pun perlu dilakukan agar masyarakat selalu ramah dan bersahabat pada wisatawan.

Daya tarik obyek wisata dan sarana pendukung secara berturut-turut merupakan indikator kedua dan keempat dalam membentuk kualitas layanan. Makna dari hasil tersebut memberikan gambaran bahwa sarana pendukung yang tersedia akan memperkuat pengaruh nilai kualitas layanan yang ditawarkan terhadap kepuasan wisatawan. Demikian juga daya tarik obyek wisata yang ditawarkan, akan memperkuat tingginya kepuasan konsumen terhadap kualitas yang ditawarkan daerah tujuan wisata Malang Raya. Untuk itu daya tarik obyek wisata tersebut patut untuk dipertahankan dan dikembangkan sehingga diharapkan wisatawan menerima kepuasan yang tinggi (very satisfy) sampai menjadi loyal. 


\section{b. Pengaruh Kualitas Layanan Secara Tidak Langsung Terhadap Image dan Melalui Kepuasan Wisatawan}

Pada tabel 5 menunjukkan bahwa kualitas layanan berpengaruh signifikan dan positif terhadap image melalui kepuasan wisatawan. Ini berarti bahwa semakin tinggi nilai kualitas layanan yang diberikan, maka secara tidak langsung melalui kepuasan wisatawan dapat meningkatkan image wisatawan terhadap daerah tujuan wisata Malang Raya. Temuan penelitian ini mendukung teori dari Gronroos (2004) yang menjelaskan bahwa image merupakan bagian penting dalam menilai kualitas jasa. Apabila dalam pikiran konsumen sudah tertanam kesan yang positif kepada perusahaan jasa tertentu, meskipun terjadi beberapa kesalahan dalam penyampaian jasa, maka kekurangan ini dapat ditutup oleh image positif ini. Hasil kajian empiris dari Kandampully dan Hu (2007) juga sejalan dengan hasil penelitian ini, dimana temuannya menjelaskan bahwa kualitas layanan berpengaruh signifikan pada image.

Demikian halnya pengaruh tidak langsungnya melalui variabel moderating kepuasan konsumen ternyata juga menghasilkan jalur yang siginifikan dengan koefisien sebesar 0,250. Jika dibandingkan dengan koefisien yang dihasilkan melalui jalur langsungnya, maka tetap pengaruh langsung dari variabel kualitas layanan terhadap image jauh lebih kuat daripada pengaruh tidak langsungnya melalui variabel kepuasan wisatawan.

\section{c. Pengaruh Kepuasan Terhadap Image Wisatawan}

Pada Tabel 5 terlihat bahwa kepuasan wisatawan berpengaruh signifikan dan positif terhadap image. Ini berarti bahwa semakin tinggi nilai kepuasan wisatawan yang diberikan oleh daerah tujuan wisata Malang Raya, maka semakin dapat meningkatkan image positif wisatawan terhadap daerah tujuan wisata tersebut. Sebaliknya semakin rendah tingkat kepuasan konsumen maka semakin dapat menciptakan image negatif konsumen.

Temuan ini sejalan dengan hasil penelitian Kandampully dan $\mathrm{Hu}$ (2007) yang menjelaskan bahwa kepuasan konsumen berpengaruh signifikan dengan image. Ini dapat diartikan bahwa penelitian yang dilakukan pada obyek dan lokasi yang berbeda dapat berlaku juga pada penelitian ini yang memilih daerah tujuan wisata sebagai obyek kajiannya. Pemenuhan kepuasan konsumen merupakan faktor penting yang akan meningkatkan image daerah tujuan wisata Malang Raya.

Kepuasan wisatawan pada daerah tujuan wisata Malang Raya akan dapat terpenuhi bila kenyataan yang mereka rasakan akan adanya daya tarik obyek wisata, sarana pendukung yang memadai, petugas yang ramah dan penduduk yang bersahabat sesuai dengan harapan. Daya tarik obyek wisata yang ditawarkan harus benar-benar bervariasi sesuai kebutuhan wisatawan. Sebagai contoh adanya wisata rekreasi yang menarik dan nyaman, wisata belanja dengan keragaman produk yang berkualitas, pelayanan dengan penuh keramahan dan harga yang bersaing. 


\title{
SIMPULAN, SARAN, DAN KETERBATASAN
}

\begin{abstract}
Simpulan
Hasil penelitian ini dapat memvalidasi semua hipotesis penelitian. Image wisatawan pada daerah tujuan wisata Malang Raya mampu dijelaskan oleh kualitas layanan baik secara langsung maupun tidak langsung melalui kepuasan wisatawan. Nilai hubungan antara kualitas layanan, kepuasan wisatawan, dan image wisatawan beserta indikator yang mempengaruhi masing-masingnya dapat berperan penting dalam menentukan rancangan strategi pemasaran guna meningkatkan image wisatawan.
\end{abstract}

\section{Saran}

Hasil studi ini memiliki implikasi penting pada pemerintah Malang Raya serta pihakpihak yang terkait dalam menetapkan strategi pemasaran yang akan memberikan added value pada daerah tujuan wisata Malang Raya antara lain:

1. Untuk menjaga daerah tujuan wisata Malang Raya sebagai daerah wisata belanja dan wisata kuliner maka pemerintah terkait harus selalu menjaga kebijakan harga yang ditetapkan terhadap semua barang dan keragaman produk yang dikonsumsi oleh wisatawan selama berada pada daerah tujuan wisata tersebut.

2. Pemerintah terkait di Malang Raya (Pemkot Malang, Pemkot Batu dan Pemkab Malang) dapat meningkatkan daya tarik objek wisata melalui penciptaan kampungkampung wisata, sebagai contoh kampung wisata keramik Dinoyo (penjualan souvenir), kampung wisata petik apel, dan kampung wisata kripik.

\section{Keterbatasan}

Selama proses penelitian ini dilakukan, dijumpai beberapa kendala dalam pengambilan data dan proses analisisnya, sehingga berakibat pada kurangnya informasi yang dapat memberikan temuan yang kurang sempurna. Adapun kendala-kendala tersebut yaitu pada proses pengambilan data, banyak responden yang cenderung memberikan jawaban pada kuesioner tidak maksimal, dengan alasan sudah capek dengan perjalanan, dan membeli oleh-oleh terutama untuk responden wanita. Hal tersebut berdampak pada pemberian nilai dalam menjawab pertanyaan yang diberikan, dimana rata-rata kecenderungan responden menjawab "setuju" pada sebagian besar partanyaan yang diajukan, sehingga untuk penelitian yang akan datang kiranya dapat dipertimbangkan untuk memberikan stimulus kepada responden. Meskipun, kemungkinan responden memberikan jawaban kurang obyektif.

Selanjutnya hasil penelitian ini belum memberikan gambaran yang utuh tentang image daerah tujuan wisata Malang Raya, mengingat penelitian tersebut baru merupakan perspektif wisatawan nusantara, sehingga dapat dilakukan penelitian selanjutnya untuk memperoleh gambaran berdasar perspektif wisatawan mancanegara. 


\section{DAFTAR PUSTAKA}

Andaleeb, SS. dan Conway. 2006. Customer Satisfaction in The Restaurant Industry: An Examination of The Transaction - Specific Model. Journal or Service Marketing 20(1): 3-11.

Anonim. World Tourism Exceed Expectations in 2007.http://www.unwto.org. Diakses 29 Januari 2008.

Barnes, JG. 2003. Secret of Costumer Relationship Management. edisi bahasa Indonesia. Yogyakarta.

Chen, C-F. dan Chen, F-S. 2010. Experience Quality, Perceived Value, Satisfaction and Behavirol Intentions For Heritage Tourists. Tourism Management 31(1): 29-35.

Correia, A and Valle, POD. 2007. Why People Travel to Exotic Places, International Journal of Culture 1(1): 45-61.

Cravens W, Piercy N. 2003. Strategic Marketing. 6 ${ }^{\text {rd }}$. North America. McGraw-Hill Higher Education.

Creswell, JW. 2009. Research Design: Qualitative, Quantitative, and Mixed Methods Approaches, $3^{\text {rd }}$, Singapore, SAGE publications, Inc.

Echtner, CM and Brent, R. 2003. The Meaning and Measurement of Destination Image. The Journal of Tourism Studies, 14(1): 1-5.

Gronross, C. 2004. Guru's View The Perceived Service Quality Concept- a Mistake?, Managing Service Quality. 11(3): 30-42.

Hair, Black, Babin, Anderson, Tathan. 2006. Multivariate Data Analysis. $6^{\text {rd. }}$ Pearson Education International.

Hanggidae, A.HJ. 2006. Strategi Pemasaran Pariwisata: Segmentation, Target Market, Positioning, dan Marketing Mix. Usahawan no.1 Januari 2006

Henderson, JC. 2002. Heritage Attractions and Tourism Development in Asia: a Comparative Study of Hongkong and Singapore. Internatonal Journal of Tourism Research 4(5): 331-334.

Hankinson, G. 2005. Destination Brand Image A Business Tourism Perspective, Journal Of Service Marketing 19(1): 24-32. 
Hutchinson, J. Lay, F. Wang, Y. 2009. Understanding The Relationships Of Quality Value, Equity, Satisfaction, And Behavioral Intentions Among Golf Travelers. Tourist Management 30 (2): 298-308.

Hui TK, Wan, D, Ho,A. 2007. Tourist Satisfaction, Recommendation and Revisiting Singapore. Tourism Management. (28): 965-975.

Ibrahim, EE dan Gill, J. 2005. a Positioning Strategy for a Tourism Destination, Based on Analysis of Customers Perception and Satisfactions. Marketing Intelegence \& Planning 23(2): 172-188.

Jasfar. 2005. Manajemen Jasa Pendekatan Terpadu, Edisi Pertama, Ghalia Indonesia. Bogor.

Juwaheer, TD. 2004. Exploring International Tourist Perceptions of Hotel Operations by Using a Modified SERVQUAL Approach a Case Study of Mauritius, Managing Service Quality 14(5): 350-364.

Kandampully, J and Suhartanto, D. 2000. Costumer Loyalty in The Hotel Industry: The Role of Costumer Satisfaction and Image, International Journal of Contemporary Hospitality Management 12(6): 346-351.

— Customer? International Journal Of Contemporary Hospitality Management 19(6): 435-443.

Kotler, P and Keller, KL. 2006. Marketing Management. $12^{\text {rd. }}$ New Jersey. Pearson Education, Inc,.

Kim, S.S, Chun, H, Petrick, J.F. 2005. Positioning Analysis Of Overseas Golf Tour Destinations By Korea Golf Tourists, Tourist Management (26): 905-917.

Kim, S.S, Agrusa J. 2004. The Positioning of Overseas Honeymoon Destination, Annals of Tourism Research 32(4): 887-904.

Liping A.Cai, Bo Hu. dan Ruomei. 2001. Domestic Tourism Demand in Dina's Urban Centres: Empirical Analysis and Marketing Implication, Journal of Vacation Marketing 8(1): 234-268.

Lien-Ti Bei, Yu-Ching, Chiao. 2001. an Integrated Model for the Effect of Perceived Product, Perceived Service Quality, and Perceived Price Fairness on Consumers Satisfaction and Loyalty. Journal of Consumer Satisfaction Dissatisfaction and Complaining Behavior 14:125-140. 
Lim, C, McAleer, M. 2001. Modeling the Determinants of International Tourism Demand to Australia, Osaka University, Japan 1-22.

Martaleni. 2010. Arti dan Pengukurann Image Daerah Tujuan Wisata, Jurnal Manajemen Gajayana (JMG) 7(1): 49-56.

, 2010. Pengembangan Pariwisata Sebagai Pemberdayaan Ekonomi Masyarakat, Prosiding Seminar Nasional Kewirausahaan I UB-Malang: 263271.

Organisasi Perburuhan Internasional (ILO). 2009. Implikasi Krisis Ekonomi Global Terhdapap Lapangan Kerja Bidang Pariwisata: studi kasus bagi Indonesia, ILO Jakarta.

Pawitra, TA and Tan, KC. 2003. Tourist Satisfaction in Singapore - a Perspective From Indonesia Tourists, Managing Service Quality 13(5): 399-411.

Parasuraman, A. 1995. Customer Service In Business-to-Business Markets: An Agenda For Research, Journal of business And Industrial marketing 13(4/5): 309 - 321.

Pitana, IG dan Diarta IKS. 2009. Pengantar Ilmu Pariwisata. Andi Offset. Yogyakarta.

Parasuraman, A, Zeithaml dan Berry, LL. 1988. SERVQUAL: A Multiple-Iten Scala for Measuring consumer Perceptions of Service Quality. Journal of Retailing 64(1): $12-40$.

.1985. A Conceptual Model Of Service Quality And Its Implications For Furture Research, Journal Of Marketing 49(4): 41-50.

Purnadi. (2009). Program Wisata Tidak Disetujui: Kalah Dengan Batu, Radar MalangJawa Pos, Rabu 4 Maret.

Rencana Induk Pengembangan Pariwisata Kabupaten Malang. 2006. Badan Perencanaan Pembangunan Daerah Kabupaten Malang.

Reisinger, Y. 1994. Tourists Perceptions of Service in Shops, International Journal of Detail and Distribution Management 22(5): 20-29.

Solimun, 2008. Memahami Metode Kuantitatif Mutakhir: Structural Equation Modeling \& Partial Least Square. Program Studi Statistika FMIPA Universitas Brawijaya.

Image Daerah Tujuan Wisata (Martaleni) 
Suradnya, I. 2008. Analisis Faktor-faktor Daya Tarik Wisata Bali dan Implikasinya Terhadap Perencanaan Pariwisata Daerah Bali.

Undang-undang Republik Indonesia no.9 Tahun 1990 Tentang Kepariwisataan

Uysal, M, Chen, JS and Williams, DR, 2000. Increasing State Market Share Through a Regional Positioning. Tourism Management 21 (1): 89-96.

White, C.J. 2004. Destination Image To See Not To See?, International Journal Of Contemporary Hospitality management 16 (5): 309-314.

Zeithaml, VA and Bitner, MJ. 2004. Service Marketing. $3^{\text {rd }}$. MC Grew-Hill Education. New York 